\title{
Update on New Species and Record of Fishes in the Coral Triangle Region for the Last 10 Years (2008-2019)
}

\author{
Fione Yukita Yalindua ${ }^{1 *}$, Teguh Peristiwady ${ }^{1}$, Putri Saphira Ibrahim ${ }^{1}$ \\ 1) Research Centre for Oceanography-LIPI, Jl Pasir Putih I Ancol Timur, Jakarta 14430, Indonesia \\ *Corresponding author, email: yukitayalindua@gmail.com
}

Submitted: 31 August 2020; Accepted: 04 January 2021; Published online: 10 March 2021

\begin{abstract}
Updated data is an essential requirement for carrying out research, planning, and policy briefs. The Coral reef triangle region is one of the areas with the highest diversity of marine biota and the discovery of new species in this area are increasing every year, much of this information is already available. However, most of the data is not available per region and is still scattered. This study aims to create a checklist and assessment of new species and a new record of fishes from this region over the last ten years based on several aspects, including species composition, pattern of distribution, endemicity, and depth using every source of the report and secondary literature data. The current new species and a new record of fish in the last decades combined consists of 360 species (268 new species and 92 new records). The most speciose group of family dominated by Gobiidae (93), followed by Labridae, Pomacentridae and Serranidae (18), Apogonidae (17), Dasyatidae (15), and the rest were ranged from 1-9 species per family. More than half of new species and new records are found in Indonesia, followed by the Philippines, Papua New Guinea, and Solomon Island. The result shows that cryptobenthic Families especially Gobiidae from genus Trimma and eviota are dominated the trend of new species and new record discovery and it is expected to rise over time while there will also be an emergence of some possibly new endemic species from major and rare families from the eastern part of Indonesia (West Papua and Papua New Guinea). Thus, the eastern part of Indonesia (Papua, Maluku, Aru Sea, and Papua New Guinea) and the northern part of Indonesia (North Sulawesi and Philippine) are suitable for exploration for marine biodiversity discovery research in the future.
\end{abstract}

Keywords: composition, coral triangle area, distribution, fish, new record species

\section{INTRODUCTION}

The availability of updated data is an essential requirement in conducted research and planning policy briefs. The Coral Triangle area is one of the locations with the highest diversity of marine biota including fishes in the world. Currently, there are 2600 species of reef fishes and it is estimated that there will be more (Tornabene et al. 2015). The coral triangle region covers $37 \%$ of the total species of reef fishes in the world and the highest concentration is located in the eastern part of Indonesia to the Philippines (Allen 2007). This finding is in line with Halas \& Winterbottom (2009) who explained that the position between West Sumatera to East Papua New Guinea and North Philippines is the area with the highest marine biodiversity 
of fishes. Every year the discovery and record of new species of fishes in the coral triangle region especially Indonesia continue to increase in the form of journal publications. Despite categorized as new information, the knowledge about these species is still considered limited and as data collection and updates are rarely displayed in broad outline, making it difficult to find relevant information with all new species and records based out of the region to see the big picture of the current status and other information regarding this issue.

Some aspect of the outline of reef fish biodiversity has been discussed by (Allen 2007; Allen \& Werner 2002; Eschmeyer et al. 2010) however this reported about 10 years ago and did not discuss details about new species, meanwhile (Drew \& Amatangelo 2017) has addressed the diversity of reef fishes but still limited to the Melanesian region including Solomon Island, Vanuatu, Fiji, and Hawaii, this emerges the need of comprehensive data that provide essential information of new species and record of fishes data that can be beneficial for researchers, students, and stakeholders to support further research and policy. The purpose of this research is to create a checklist and assessment based on comprehensive data and outline related to the discovery progress of new species in the coral triangle area as a marine hotspot for biodiversity of marine biota in addition to information on new records of fishes for the last ten years.

\section{MATERIALS AND METHODS}

The scope of data is restricted to the year 2008 to the early half of 2019. Data collection was conducted using secondary literature study methods from FishBase (roese \& Pauly 2019), Eschmeyers Catalog of Fishes (Eschmeyers \& Vander Laan 2019), and other related scientific publications and books. Data then compiled in the form of a checklist which includes ordo, families, genera, species name, country, discovery area, depth, year found, year of publication, status, collector, gear, and referral journal. The status in the checklist is a group in two terms which are new species and new record category, the new species is categorized as a species that newly discovered and described or re-described by taxonomist as a new species in the world or novel species based on the location of the holotype (main specimen for description) for the last 10 years. Meanwhile, the term new record refers to species that already being described by taxonomist, distributed and reported in some area outside of the coral triangle area before but recently found and reported in a new region for the first time in the last ten years (in this case coral triangle region) and/ or use as a paratype (supporting specimen). Thus, new species can also be categorized as a new record based on new species reported in some areas. However, because some of the species included in new records are not novel species in the last 10 years and already described before, and most publications conclude the term new species and new records as separate terms, then we group it in two different categories. Based on the data compiled, the point location maps and distribution were asses using QGIS software.

\section{RESULTS AND DISCUSSION}

\section{Biodiversity and composition of fishes}

According to data on new species and records of fishes for the last decade compiled in this study, the addition of species and new records is quite high for an area. This finding indicates that there is still a potential for high biodiversity that still needs to be explored. The proportion of combination of new species and new records fish found in each country which part of Coral Triangle Area (Indonesia, Philippines, Papua New Guinea, and Solomon 
a.

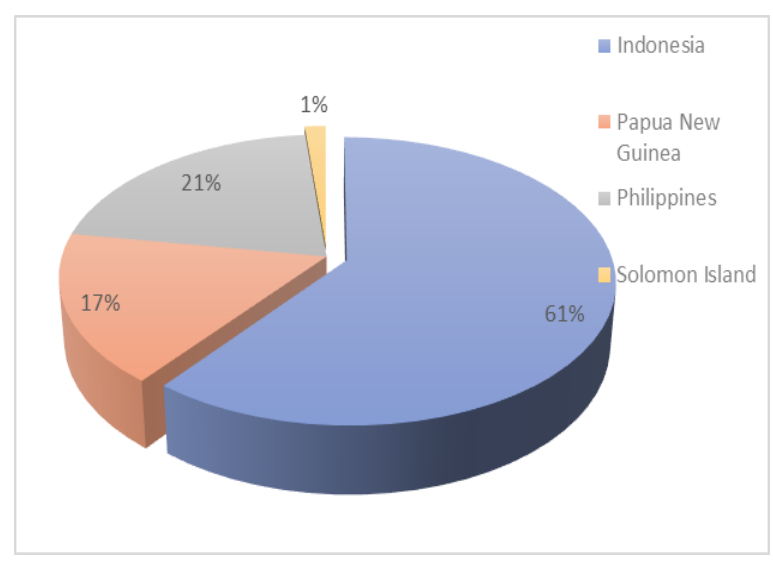

b.

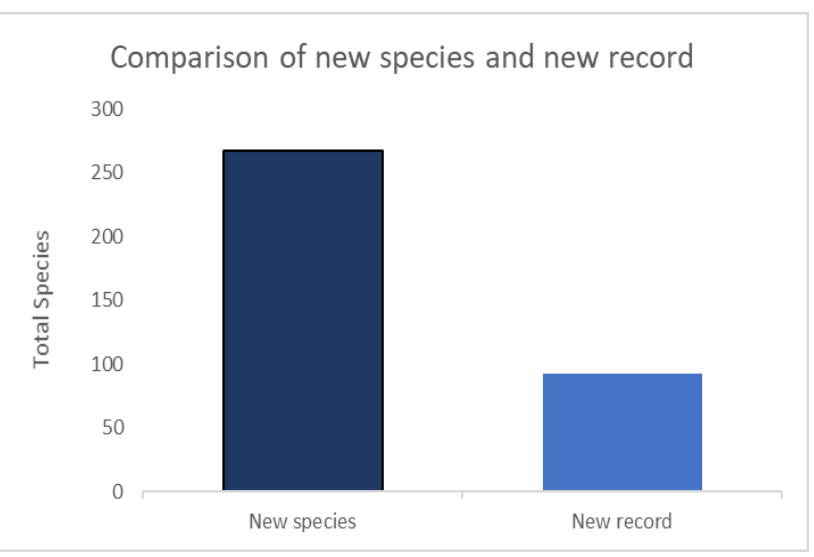

Figure 1. a. The proportion of new species and new records found in each country b. Comparison of new species and new records in the Coral Triangle Area.

Islands) are shown in Figure 1a. Figure 1b highlights the comparison of new species and a new record of fishes in the coral triangle area.

Based on the result of data for the last 10 years (mid-2008 to early 2019), a total number of 360 species which are the combination of new species and new record fishes were obtained consist of 31 orders, 80 families, and 170 genera from 4 countries which include Indonesia with 206 species, Papua New Guinea (58), Philippines (70) and Solomon Island (5) (Figure 1). The rest 21 species are the combined results of several countries in the coral triangle area with similar specimens of species in the form of paratypes based on observations during literature studies. For example, a new species Parascombrops glossodon is described based on holotype (main specimen for description) in Philippines. However, this species is also distributed in Indonesia and collected as a paratype (supporting specimen for reference). Trimma maiandros is a new record reported from the coral triangle region (Indonesia, Phillipines, Papua New Guinea, and Solomon Island) from previously reported in Japan, Australia, and Samoa (Hoese et al. 2011). Two hundred sixty-eight species are included in the new species category and 92 species are in the new record category (Figure 1b). The term of new record defines a species found in a new region that indicates a wider distribution record from previous reports. This could be caused by several factors including some species are described as new species only based on one or several specimens and as it is considered new there is limited knowledge about this particular species distribution (Peristiwady 2011) and limited records of monitoring and migration of fishes due to climate change (Gamito et al. 2016). In addition, the collection of new records data also have an important role in establishing a database, even though update of fishes record in monitoring results such as checklists and scientific journal publications are not always included in databases such as Fishbase, Catalog of Fishes and other.

From the total species and new records of fishes sorted by countries in coral triangle region, Indonesia contributed a total number of $57 \%$ represented by new species, new record in order $(151,55)$ followed by Philippines 20\% (59,11), Papua New Guinea 16\% (48,10) whereas Solomon Island contributed only $1 \%(5)$ and the rest $6 \%$ is the combination of some of these countries $(1,20)$. The trend of the total species addition is positively correlated with the total area of coral reefs and the total number of fishes that have been previously reported. Indonesia with an area of coral reefs reaching approximately $51.020 \mathrm{~km} 2$ has the highest total number of fish 
species in the coral reef triangle region with a recorded number of about 2200 species, whereas Philippines reported consist of $25,060 \mathrm{~km}^{2}$ coral reefs area and 1790 reef fishes species, Papua New Guinea consist of $13,840 \mathrm{~km}^{2}$ with 1635 reef fishes species and Solomon Island with an area of coral reef about $5750 \mathrm{~km}^{2}$ and recorded 1371 reef fishes species (Allen 2007). Areas with centers of diversity of coral reef fishes are located from Eastern Indonesia to Philippines, we highlighted Papua island in Indonesia as the region that contributes the most diversity of new species fishes, on a small part of the island alone such as the Birds Head Peninsula record approximately 1511 species and the data continues to increase (Allen \& Erdmann 2009).

Figure 2 shows fish family composition based on the publication year (2008-2019) fluctuates and does not indicate an up or down trend. However, consistently the Gobiidae family is the most dominant with a total number of 93 species, followed by Labridae, Pomacentridae and Serranidae (18), Apogonidae (17), Dasyatidae (15), and the rest are ranges from 1-9 species per family. Gobiidae is a family with the most abundant number of species and during the last 10 years, Trimma and Eviota are the most common genera described as new species. Individuals from this genus belong to the cryptic type with a size of less than $5 \mathrm{~cm}$ and are associated with benthos (Goatley \& Brandl 2017). Exploration of these genera can be categorized as new in recent decades by the growing development of scuba-diving equipment for ichthyologists. For example, the Trimma genus consists of only about ten species in 1970 increased to at least up to100 valid species in 2019 (Allen 2019). The number of species of this genus is increasing every year and in recent reports, species from this genera are included in the highlyendemic cryptic species which indicates the trend of species from these genera in the coral reef region will continue to be discovered. (Tornabene et al. 2015), Although this family genus is still largely ignored in the visual census (Brandl et al. 2018) due to its small-sized body, which is difficult to observe in the habitat.

Most Serranidae families are included in the new record status and the majority are recorded from North Sulawesi. This could be due to the condition of the region directly facing the Pacific Ocean and also consistent monitoring is carried out at several fish landing sites (Peristiwady 2011; Peristiwady et al. 2014; Uiblein et al. 2017; Peristiwady et al. 2018) which indicates consistent monitoring has the potential to add many new records of fish in Indonesia and other regions in the coral triangle area. Other families such as Labridae, Pomacentridae, and Apogonidae are families with the most abundance of species diversity in the world consist of 557, 422, and 381 valid species respectively (Eschmeyer \& Vander Laan 2019). Most of the new species discovered in the world over the past ten years have been found in the coral triangle region, for example, 18 species out of 45 (world) for Labridae, 18 out of 33 (world) for Pomacentridae, and 18 out of 31 (world) for Apogonidae while most species and new records of Dasyatidae family are recorded from the coral triangle area which is 15 species out of 20 species (world).

The publication year (Figure 2) shows the average number of species added each year ranges from $20-30$ species. The least number of species in 2018-2019 due to the data records in some databases are not consistently updated for the latest years. Data collection from secondary sources from journal publications conducted by the author only consists of half the year 2019 which we expected the total of species in 2019 would be increasing in Figure 2. The high number of new species published in 2012 is due to the publication of the book by Allen and Erdmann (2012) that adds up the description of 25 species and several new fish records that are mostly 


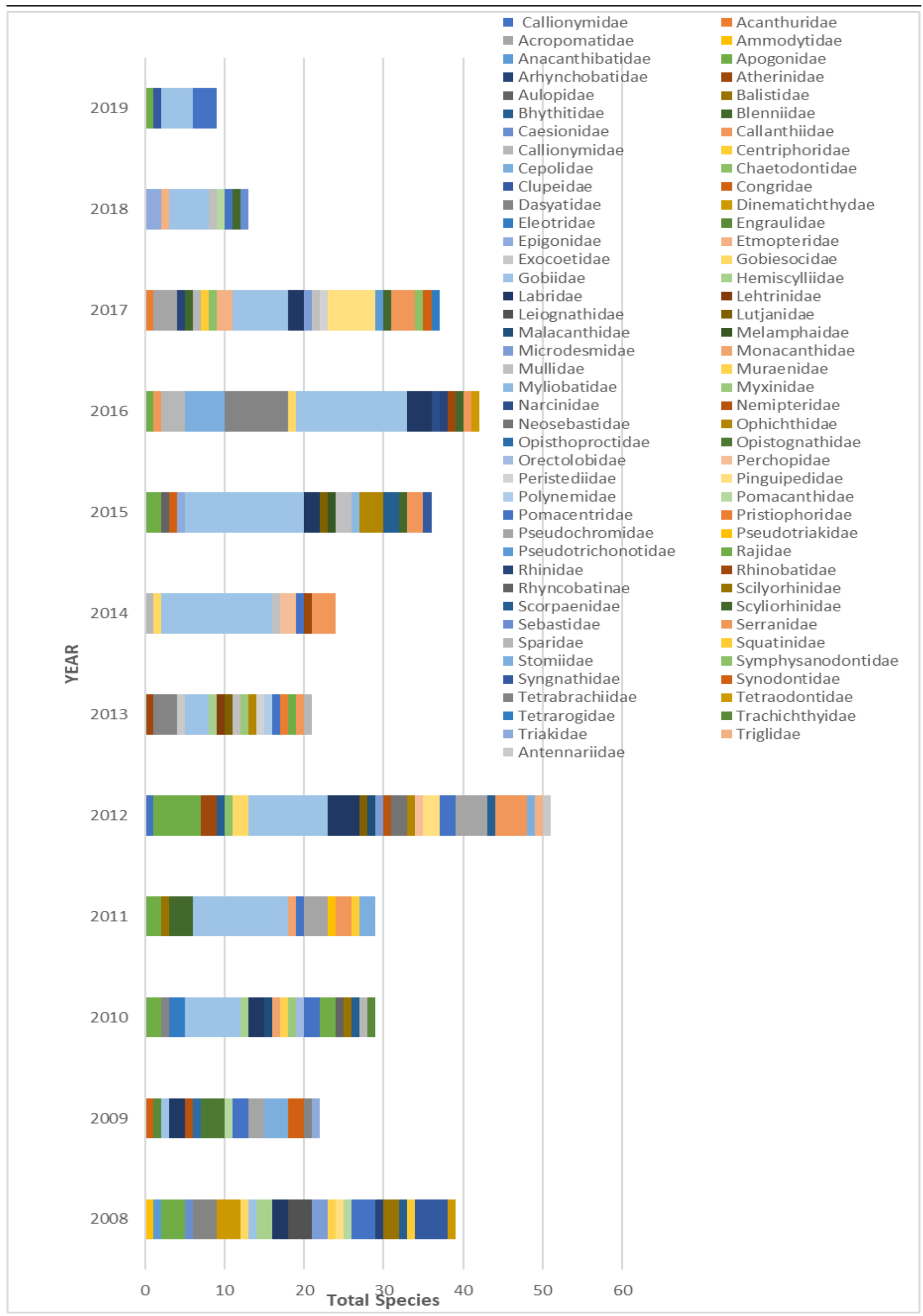

Figure 2. Family composition based on publication year. 
originating from countries in the coral reef triangle region.

Distribution of new species and record of new fishes

New species and new records of fishes found in the Coral Triangle also are distributed in several countries and regions other than coral reef triangle areas such as the Southwest Pacific (New Zealand), Indian Ocean (Africa), Eastern Indian Ocean (Australia), and Countries in the Pacific (Japan, Taiwan, China) and South Pacific Ocean (Solomon Island, Vanuatu, Hawaii) (Table 1). This indicated the distribution patterns of some recent fish records referring to fairly wide distribution especially for species with high larval dispersal rate, swimming ability, and no habitat fragmentation (barrier) (Franco et al. 2012). For example some specious fishes from family Gobiidae, Pomacentridae, Serranidae, Labridae, and others which are distributed in almost all region of ocean in the world (Hixon \& Randall 2019) in line to the statement by Kulbicki et al. (2013) that this phenomenon caused by extensive dispersal patterns and other evidence of evolution. The pattern of new records of fishes found fits the location and sea area, for example, new records found in the region of Sulawesi, Indonesia distributed fairly in the Pacific Ocean region like Japan (21), Taiwan (10), China (3), and Palau (7) (Burhanuddin et al. 2017; Peristiwady et al. 2014) (Table 1). On the other hand, new records found in the West Papua region and parts of Java and Nusa Tenggara have similarities with species recorded from Australia (12), New Caledonia (8), and other Micronesia region (Vanuatu, Fiji, Samoa, etc) (Last et al. 2006, 2008; Last \& White 2008).

Table 1. New species and records of fishes and number of species in coral triangle area which are also distributed in other countries.

\begin{tabular}{|c|c|c|c|c|}
\hline \multirow[b]{2}{*}{ Country } & \multicolumn{4}{|c|}{ Distribution } \\
\hline & New Species & $\begin{array}{l}\text { Number } \\
\text { of species }\end{array}$ & New record & $\begin{array}{c}\text { Number of } \\
\text { species }\end{array}$ \\
\hline \multirow[t]{25}{*}{ Indonesia } & Australia & 5 & Caribbean & 1 \\
\hline & India & 4 & Africa & 2 \\
\hline & Japan & 2 & Australia & 12 \\
\hline & Malaysia & 3 & Japan & 21 \\
\hline & Brunei & 1 & Taiwan & 10 \\
\hline & Maldives & 1 & New Caledonia & 8 \\
\hline & Srilanka & 1 & China & 3 \\
\hline & Japan & 4 & New Zealand & 1 \\
\hline & Myanmar & 1 & Fiji & 1 \\
\hline & Vanuatu & 2 & Maldives & 2 \\
\hline & Singapore & 3 & Samoa & 3 \\
\hline & Thailand & 2 & Palau & 7 \\
\hline & Palau & 1 & Polinesia & 1 \\
\hline & China & 1 & Singapore & 1 \\
\hline & Taiwan & 1 & Somalia & 1 \\
\hline & Tanzania & 1 & India & 1 \\
\hline & Africa & 1 & Oman & 1 \\
\hline & $\begin{array}{l}\text { Papua New } \\
\text { Guinea }\end{array}$ & 18 & Pakistan & 1 \\
\hline & Philippines & 14 & Srilanka & 1 \\
\hline & Solomon Island & 8 & Thailand & 1 \\
\hline & & & Brunei & 2 \\
\hline & & & Papua New & 5 \\
\hline & & & Guinea & \\
\hline & & & Philippines & 4 \\
\hline & & & Solomon Island & 3 \\
\hline
\end{tabular}


Table 1. Contd.

\begin{tabular}{|c|c|c|c|c|}
\hline \multirow[b]{2}{*}{ Country } & \multicolumn{4}{|c|}{ Distribution } \\
\hline & New Species & $\begin{array}{l}\text { Number } \\
\text { of species }\end{array}$ & New record & $\begin{array}{c}\text { Number of } \\
\text { species }\end{array}$ \\
\hline \multirow{13}{*}{$\begin{array}{c}\text { Papua New } \\
\text { Guinea }\end{array}$} & Malaysia & 1 & Australia & 6 \\
\hline & Japan & 1 & China & 1 \\
\hline & Vanuatu & 1 & France & 1 \\
\hline & Indonesia & 6 & India & 1 \\
\hline & Phillipines & 2 & Japan & 2 \\
\hline & Solomon Island & 2 & Kenya & 1 \\
\hline & & & Korea & 1 \\
\hline & & & Africa & 2 \\
\hline & & & Fiji & 2 \\
\hline & & & Vietnam & 1 \\
\hline & & & Thailand & 1 \\
\hline & & & Fiji & 1 \\
\hline & & & Samoa & 1 \\
\hline \multirow[t]{13}{*}{ Philippines } & Australia & 1 & Australia & 4 \\
\hline & Brunei & 1 & Japan & 5 \\
\hline & Hawaii & 1 & China & 1 \\
\hline & Malaysia & 3 & New Caledonia & 1 \\
\hline & Japan & 3 & Taiwan & 1 \\
\hline & Nicaragua & 1 & Vanuatu & 3 \\
\hline & Fiji & 1 & Maldives & 1 \\
\hline & $\begin{array}{l}\text { French } \\
\text { Polynesia }\end{array}$ & 1 & & \\
\hline & Vanuatu & 1 & & \\
\hline & New Caledonia & 1 & & \\
\hline & Indonesia & 6 & & \\
\hline & $\begin{array}{l}\text { Papua New } \\
\text { Guinea }\end{array}$ & 2 & & \\
\hline & Solomon Island & 1 & & \\
\hline \multirow{2}{*}{$\begin{array}{l}\text { Solomon } \\
\text { Island }\end{array}$} & New Caledonia & 1 & & \\
\hline & $\begin{array}{l}\text { Papua New } \\
\text { Guinea }\end{array}$ & 1 & & \\
\hline
\end{tabular}

The present study indicates that several new species are currently considered endemics. Allen et al. (2018) reported that some species recorded in the last 10 years in the West Papua region, especially Fakfak Peninsula such as Scorpaenodes bathycolus (Scorpaenidae), Chrysiptera giti, Pomacentrus fakfakensis (Pseudochromidae), Paracheilinus nursalim (Labridae), and Pomacentrus bellipictus (Pomacentridae) are indicated belong to the local microendemic fishes. Some unique species from Hemischylidae or walking sharks consist of only 17 species globally, and 4 of them are described in the last ten years originating from the eastern part of Indonesia (Ternate and Papua). The rest that has been described previously are scattered mostly in West Papua and Papua New Guinea. This is due to their limited swimming and dispersal ability resulting in most species of this genus has a restricted distribution (Allen et al. 2013) and potentially be put in the endemic species category. Family of Pomacentridae such as Chromis Athena, Chromis unipa, and Pomacentrus Fakfakensis are endemic species found only in West Papua, as well as Pseudochromis ammeri (Pomacentridae), while some species that are classified as endemic from the Ambon and Merauke regions including Hemytrigon longicauda (Dasyatidae) and Sueviota bryozophila (Gobiidae), from Philippine 
Branchiostegus saitoi (Malacanthidae) 2012 and Pseudochromis eichleri

(Pseudochromidae) 2012 are some examples of endemic species from that region. It is estimated that more endemic species will be expected, as several species are still being studied and some data are needed before they are included as endemic species.

Figure 3 shows that mostly major families (most abundance species) are spread in almost all countries in the coral reef triangle area, most families
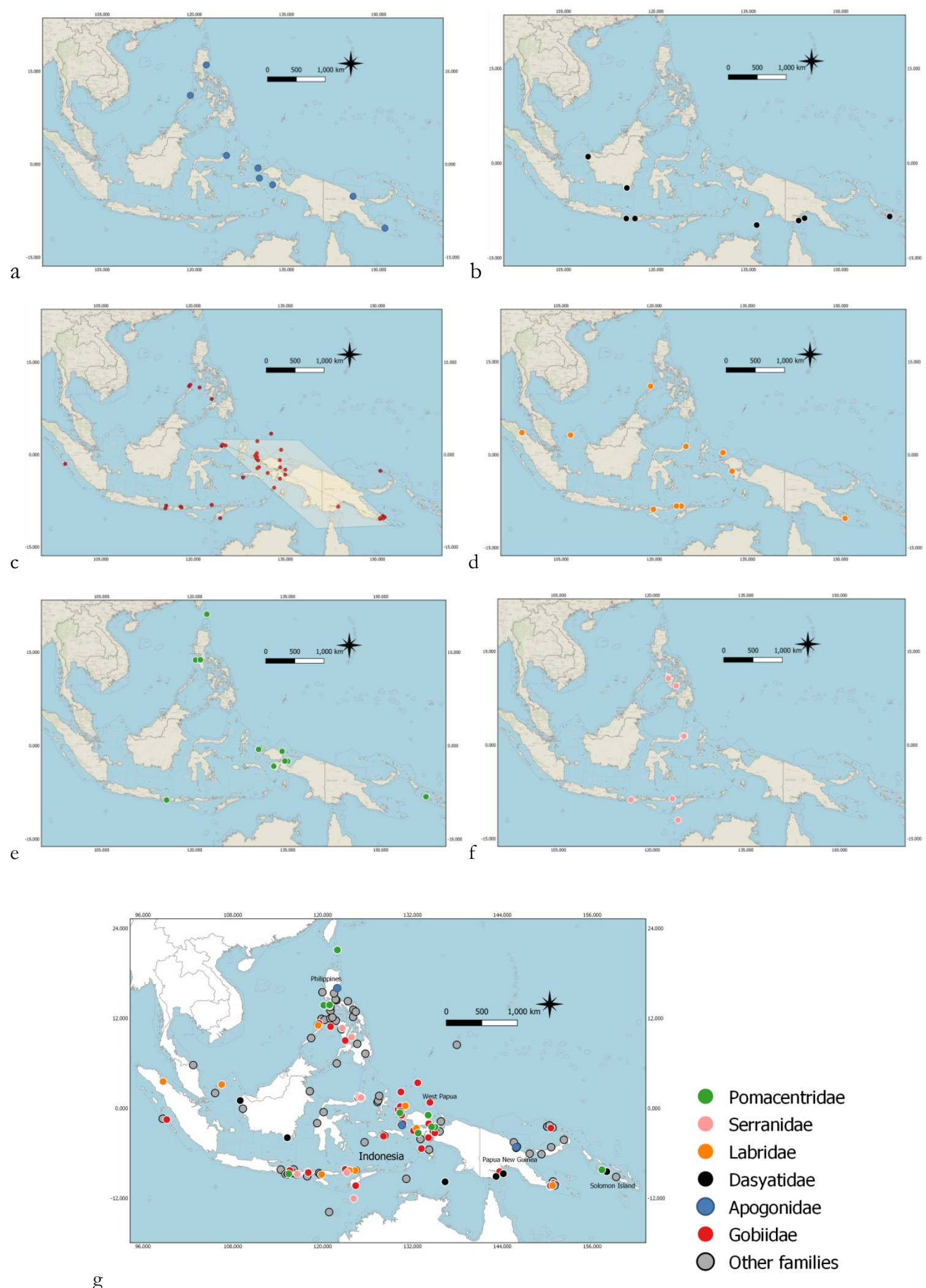

Figure 3. Location points for new species and records of fishes in several major families a. Apogonidae, b. Dasyatidae, c. Gobiidae, d. Labridae, e. Pomacentridae, f, Serranidae, g. Combination of major and the other family. 
such as Gobiidae are found in many regions of West Papua, Papua New Guinea towards Sulawesi and Philippines that can be correlated with their habitats which are generally located in coral reef areas, sand, rubble, and seagrass beds due characteristic of the species living patterns that tend to hide from predators (Herler et al. 2011) the existence of species from these families in coral reefs contributes significantly to the transfer of energy to the ecosystems due to their fast life cycle and as the source of energy or food for marine biota, due to some of the properties of these species are specialized in certain types of coral (Herler et al. 2011) it created the possibility of endemic species records from the Gobiidae families is expected to rise over time, while it is also correlated directly to the damage of coral reefs that could threaten the existence of some species in this family that specialize in specific types or species of coral reefs. A total of 15 species from the Dasyatidae or stingray family have a somewhat different location pattern compared to some other families, because these new species are found in Kalimantan, Java and the lower part of the island of Papua (Papua New Guinea and Solomon Island, nonetheless there is no striking difference for families such as Labridae, Serranidae, and Apogonidae which are found in almost all regions in Indonesia, Philippines, Papua New Guinea, and Solomon Island, but in terms of the abundance, the majority of all new species found are located in West Papua province, Indonesia especially locations such as Raja Ampat and Birdhead Peninsula (FakFak), Misool, parts of Maluku and the Aru Sea, North Sulawesi (Lembeh strait and Bunaken), East Nusa Tenggara, and West Nusa Tenggara followed by parts of Papua New Guinea (Milne Bay, Alotau) and Philippine (Palawan, Iloilo), this finding is in line with (Allen 2007) who report a large degree of diversity and also endemicity which lead to conclusion that these area are very potential as a hostspots for studying marine biodiversity, especially reef fishes, and a potential destination to explore existing marine biodiversity for researcher due to the fact that new species and record discovery at this region is consistent every year and continues raise up.

\section{Classification of fishes based on depth}

All kind of different species and new records of fishes are found in a different range of depth which was shallow water (0-50m), intermediate (50$200 \mathrm{~m})$, and deep water $(>200 \mathrm{~m})$ but not all are shown in Table 2 due to limited data in the publication journal. In general, the majority of the species are had associated habitats in shallow water and the rest are found in-depth more than $50 \mathrm{~m}$. One of the factors is coastal fish are the most abundant in the world (Eschmeyer et al. 2010). Most species that live in shallow water associated with the reef fish family including Gobiidae, Apogonidae, Blennidae, etc. Species found in-depth range around 50-200 m are classified as a demersal benthopelagic (Mauchline \& Gordon 1986) that live in the deep sea and forage in the coral reef ecosystems such as species from Serranidae families, Mullidae, and Dasyatidae. Despite the fact that some other species classified as reef fish and associated with shallow water can be found in these depths such as Pomacentridae and several species of Gobiidae (Prokofiev 2017; Pyle \& Earle 2008). Other species that are located at a depth of $>200 \mathrm{~m}$ are a type that is classified as deep-sea fish including Cepolidae families (William \& Johnson 2016), Stomiidae (Flynn \& Klepadlo 2012), Trigilidae, and some new records from the Serranidae family including Plectranthias (Peristiwady et al. 2018) from North Sulawesi. Plectranthias is probably a rare collection because most of the valid species of this genus are described only from one or two specimens in the world (Eschmeyer et al. 2010). 
Table 2. New species and record of fishes based on depth.

\begin{tabular}{cccc}
\hline Country & \multicolumn{3}{c}{ Range of depth } \\
\hline & $0-50 \mathrm{~m}$ & $50-200 \mathrm{~m}$ & $>200 \mathrm{~m}$ \\
\hline Indonesia & 109 & 42 & 14 \\
Papua New Guinea & 43 & 10 & 12 \\
Philippines & 18 & 24 & 23 \\
Solomon Island & 5 & 0 & 0 \\
\hline
\end{tabular}

Collection of specimens from fishes at different depths requires different methods and approaches, from various fishing gear compiled in the checklist, it can be concluded that trawling and hook and line are the majority of fishing gear used to collect deep-sea fish at depths $>200 \mathrm{~m}$, while hook and line, clove oil and collections from the market (fishermen) become a collection method for fish in the depths of 50-200 m, moreover fishes in shallow water are usually collected by hand, hand net, spear anesthetized with clove oil, and rotenone during SCUBA. However, the use of rotenone in recent years has been controversial (Robertson \& Smith-Vaniz 2008); hence the use of Clove oil is becoming a more environmentally friendly choice for collecting and anesthetized small fish in the coral reef ecosystem (Robertson \& Smith-Vaniz 2010).

\section{CONCLUSION}

This study supports the application of the marine biodiversity informatics database to give a comprehensive outline related to the discovery progress of new species in the coral triangle area as a marine hotspot for biodiversity of marine biota in addition to information on new records of fishes for the last ten years. Here author demonstrated analysis from a different type of information that was formed from the data compilation including the composition and distribution of new species and records of fishes. This study found that the trend in the total of species addition is positively correlated with the total area of coral reefs in a particular region or country and the total number of coral fishes previously reported and distributed in that region. The Majority of new species found are located in the eastern part of Indonesia (Papua, Maluku, Aru Sea, and Papua New Guinea) and the northern part of Indonesia (North Sulawesi and Philippine), in addition, the endemic species from these locations (West Papua) is estimated to increase. It is a suitable area for exploration for marine biodiversity research in the future and important to be prioritized as a protected reserve in the coral reef region.

\section{AUTHORS CONTRIBUTION}

F.Y., T.P. and P.S.I. collected the data; F.Y. and T.P. analyzed the data; F.Y. wrote the paper; all authors have reviewed the final version of the manuscript and approved it for publication.

\section{ACKNOWLEDGMENTS}

We would like to thank Marine Biota Conservation Research Group Bitung for the insight and highlight of the important information about the ecological situation in Papua and North Sulawesi and for providing the author with journal especially the new record of fishes in Indonesia.

\section{CONFLICT OF INTEREST}

The authors state there is no conflict of interest. 


\section{REFERENCES}

Allen, G.R. \& Werner, T.B., 2002. Coral reef fish assessment in the "coral triangle" of southeastern Asia. Environmental Biology of Fishes, 65(2), pp.209-214.

Allen, G.R., 2007. Conservation hotspots of biodiversity and endemism for Indo-Pacific coral reef fishes. Aquatic Conservation: Marine and Freshwater Ecosystems, 656(18), pp.541-556.

Allen, G.R. \& Erdmann, M. V., 2009. Reef fishes of the Bird's Head Peninsula, West Papua, Indonesia. Check List, 5(3), pp.587-628.

Allen, G.R. \& Erdmann, M. V, 2012. Reef fishes of the East Indies Tropical reef research, ed., Perth, Australia: Universitiy of Hawai'i Press.

Allen, G.R., Erdmann, M. V. \& Dudgeon, C.L., 2013. Hemiscyllium halmahera, a new species of Bamboo Shark (Hemiscylliidae) from Indonesia. Aqua, International Journal of Ichthology, 19(3), pp.123-136.

Allen, G., Erdmann, M. \& Hidayat, N., 2018. Pomacentrus bellipictus, a new microendemic species of damselfish (Pisces: Pomacentridae) from the Fakfak Peninsula, West Papua, Indonesia. Journal of the Ocean Science Foundation, 30(2018), pp.1-10.

Allen, G., 2019. Trimma christianeae, a new species of goby (Teleostei: Gobiidae) from Milne Bay Province, Papua New Guinea. Journal of the Ocean Science Foundation, 32(January 2019), pp.39-46.

Brandl, S.J. et al., 2018. The hidden half: ecology and evolution of cryptobenthic fishes on coral reefs. Biological Reviews, 93(4), pp.18461873.

Burhanuddin, A.I. et al., 2017. New record of the golden grouper Saloptia powelli (Perciformes: Serranidae) from North Sulawesi, Indonesia. Journal of Ichthyology, 57(2), pp.337-340.

Drew, J.A. \& Amatangelo, K.L., 2017. Community assembly of coral reef fishes along the Melanesian biodiversity gradient. PLOS ONE, 12(10), pp.1-17.

Eschmeyer, W.N. et al., 2010. Marine fish diversity: History of knowledge and discovery (Pisces). Zootaxa, 50(2525), pp.19-50.

Eschmeyer, F.R. \& Vander Laan, R., 2019. Eschmeyer's Catalog Of Fishes: Genera, Species, References, viewed 20 April 2019 from http:/ / researcharchive.calacademy.org/research/ichthyology/catalog/ fishcatmain.asp.

Flynn, A.J. \& Klepadlo, C., 2012. Two new species of Photonectes (Teleostei: Stomiidae) from the Indo-Pacific, and a re-examination of P. Achirus. Memoirs of Museum Victoria, 69, pp.259-267.

Franco, A. Di et al., 2012. Dispersal Patterns of Coastal Fish : Implications for Designing Networks of Marine Protected Areas. , 7(2).

Froese, R. \& Pauly, D., 2019. FishBase, viewed 20 April 2019 from www.fishbase.org.

Gamito, R. et al., 2016. Trends in landings and vulnerability to climate change in different fleet components in the Portuguese coast. Fisheries Research, 181, pp.93-101.

Goatley, C.H.R. \& Brandl, S.J., 2017. Cryptobenthic reef fishes. Current Biology, 27(11), pp.R452-R454.

Halas, D. \& Winterbottom, R., 2009. A phylogenetic test of multiple proposals for the origins of the East Indies coral reef biota. Journal of Biogeography, 36(10), pp.1847-1860.

Herler, J., Munday, P.L. \& Hernaman, V., 2011. Gobies on coral reefs. The Biology of Gobies, (September 2011), pp.493-529.

Hixon, M.A. \& Randall, J.E., 2019. Coral reef fishes. Encyclopedia of Ocean Sciences, pp.142-150. 
Hoese, D.F., Winterbottom, R. \& Reader, S., 2011. Trimma maiandros, a new species of pygmy goby (Gobiidae) from the Indo-west Pacific. aqua: International Journal of Ichthyology, 17, p.103+.

Kulbicki, M. et al., 2013. Global biogeography of reef fishes: A hierarchical quantitative delineation of regions. PLoS ONE, 8(12), pp.1-11.

Last, P.R., Séret, B. \& Wh, T., 2006. New swellsharks (Cephaloscyllium : Scyliorhinidae) from the Indo - Australian region. CSIRO Marine and Atmospheric Research Paper, 22, pp.129-146.

Last, P.R., Manjaji-matsumoto, B.M. \& Pogonosk, J.J., 2008. Himantura astra sp . nov ., a new whipray (Myliobatoidei : Dasyatidae) from northern Australia. CSIRO Marine and Atmospheric Research Paper, 2(2004), pp.303314.

Last, P.R. \& White, W.T., 2008. Dasyatis parvonigra sp. nov., a new species of stingray (Myliobatoidei: Dasyatidae) from the tropical eastern Indian Ocean. Marine and Atmospheric Research, 22, pp.275-282.

Mauchline, J. \& Gordon, J., 1986. Foraging strategies of deep-sea fish. Marine Ecology Progress Series, 27(1978), pp.227-238.

Peristiwady, T., 2011. First record of Odontanthias unimaculatus (Tanaka 1917) (Perciformes: Serranidae) from Indonesia. Biodiversitas, Journal of Biological Diversity, 12(1), pp.136-140.

Peristiwady, T., Makatipu, P.C.H. \& Du, J., 2014. Short communication: A new record of Giganthias immaculatus Katayama, 1954 (Perciformes: Serranidae) from Indonesia. Biodiversitas, 15(1), pp.104-107.

Peristiwady, T. et al., 2018. Plectranthias kamii Randll, 1980 (Perciformes: Serranidae) collected from Bitung, North Sulawesi: first record from the Southwest Pacific Ocean. Acta Oceanologica Sinica, 37(12), pp.73-77.

Prokofiev, A.M., 2017. New genus of Ptereleotrinae (Gobioidei) from the South China Sea. Journal of Ichthyology, 57(1), pp.158-160.

Pyle, R. \& Earle, J.L., 2008. Five new species of the damselfish genus Chromis (Perciformes: Labroidei: Pomacentridae) from deep coral reefs in tropical western Pacific. Zootaxa, 31, pp.3-31.

Robertson, D.R. \& Smith-Vaniz, W.F., 2008. Rotenone: An Essential but Demonized Tool for Assessing Marine Fish Diversity. BioScience, 58(2), pp.165-170.

Robertson, D.R. \& Smith-Vaniz, W.F., 2010. Use of clove oil in collecting coral reef fishes for research. Marine Ecology Progress Series, 401, pp.295302.

Tornabene, L. et al., 2015. Support for a "Center of Origin" in the Coral Triangle: Cryptic diversity, recent speciation, and local endemism in a diverse lineage of reef fishes (Gobiidae: Eviota). Molecular Phylogenetics and Evolution, 82(PA), pp.200-210.

Uiblein, F., Gledhill, D.C. \& Peristiwady, T., 2017. Two new goatfishes of the genus Upeneus (Mullidae) from Australia and Indonesia. Zootaxa, 4318(2), pp.295-311.

William, F.S.V. \& Johnson, G.D., 2016. Hidden diversity in deep-water bandfishes: Review of Owstonia with descriptions of twenty-one new species (Teleostei: Cepolidae: Owstoniinae). Zootaxa, 4187(1), pp.1-103. 